\title{
MACROECONOMIC POLICY
}




\section{MACMILLAN NEW STUDIES IN ECONOMICS}

\section{Published}

Brian Burkitt and David Bowers

TRADE UNIONS AND THE ECONOMY

Keith Cuthbertson

MACROECONOMIC POLICY: THE NEW CAMBRIDGE, KEYNESIAN AND MONETARIST CONTROVERSIES

M. C. Howard

MODERN THEORIES OF INCOME DISTRIBUTION

Homa Katouzian

IDEOLOGY AND METHOD IN ECONOMICS 


\section{MACROECONOMIC POLICY}

\section{THE NEW CAMBRIDGE, KEYNESIAN AND MONETARIST CONTROVERSIES}

Keith Cuthbertson

Senior Lecturer in Economics at Thames Polytechnic

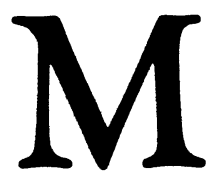


(C) Keith Cuthbertson 1979

All rights reserved. No part of this publication may be reproduced or transmitted, in any form or by any means, without permission.

First edition 1979

Reprinted 1982, 1983

Published by

THE MACMILLAN PRESS LTD

London and Basingstoke

Companies and representatives

throughout the world

Typeset by Preface Ltd, Salisbury, Wiltshire

\section{British Library Cataloguing in Publication Data}

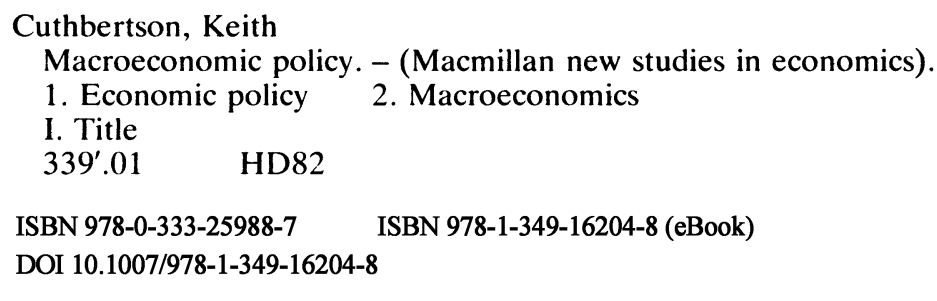

The paperback edition of this book is sold subject to the condition that it shall not, by way of trade or otherwise, be lent, re-sold, hired out, or otherwise circulated without the publisher's prior consent in any form of binding or cover other than that in which it is published and without a similar condition including this condition being imposed on the subsequent purchaser. 


\section{To Theo and Leon}

Concern for man himself and his fate must always form the chief interest for all technical endeavours. . . Never forget this in the midst of your diagrams and equations.

ALBERT EINSTEIN

Speech given at the California Institute of Technology, 1937 


\section{Contents}

Preface ix

Acknowledgements xiii

1 An Overview 1

Keynesian views 2

Monetarist views $\quad 7$

New Cambridge views $\quad 12$

The macroeconomic performance of the U.K. economy, 1961-77 15

The structure and philosophy of the book 19

2 Keynesian Views 23

The structure of Keynesian models $\quad 24$

Simulation results $\quad 39$

Policy implications of the simulation results 47

The forecasting accuracy of Keynesian models $\quad 50$

3 New Cambridge Views 53

Flow-of-funds analysis and the net acquisition of financial assets of the private sector $\quad 54$

The structure of the New Cambridge model 57

Simulation results and policy conclusions $\quad 75$

4 Monetarist Views $\quad 90$

The structure of Monetarist models $\quad 91$

The behaviour and policy implications of Monetarist models of open economies with perfectly flexible exchange rates

The behaviour and policy implications of Monetarist models of small open economies with fixed exchange rates

5 Analysis and Synthesis 147

An assessment of some structural relationships $\quad 151$

Policy alternatives 
viii

Contents

Appendix 1: Some Mathematical and Statistical Techniques 169

Selected Reading 181

Notes and References 184

Bibliography

193

Index

204 


\section{Preface}

Any new textbook worthy of consideration should aim to fill a gap in the market, if only in an attempt to maximise the author's expected remuneration. A large number of undergraduate macroeconomics texts devote considerable space to an analysis of the theoretical aspects of individual behavioural equations in the economy such as the consumption, investment and demand for money functions but spend little time in drawing out the detailed workings and quantitative policy implications of the complete models implied by these behavioural equations. At the other end of the spectrum numerous texts present a purely verbal account of the macroeconomic policy implications of various schools of thought without an adequate analysis of the crucial behavioural relations that underly such views. It is the aim of this text to bridge this gap and by so doing to assess the ability of three main alternative schools of thought in explaining and forecasting the behaviour of industrialised economies, particularly the U.K. economy. Essentially, then, the book is best viewed as an introduction to the use of models in empirical macroeconomic analysis and policymaking.

The book is aimed primarily at second- and third-year students doing either an economics degree or general social science degrees (such as business studies, marketing, or politics) which include economics as a major area of study. With its emphasis on macroeconomic policy debates it would seem to be a fairly comprehensive and useful macroeconomics text for this latter group as well as for professional economists in industry, teaching and the public sector who may wish to 'brush up' their knowledge in this area.

It is assumed that the reader is familiar with the simple Keynesian expenditure model and the behavioural equations that underlie it. An elementary knowledge of money-supply 
determination and the demand for money function would be an advantage. Mathematics and statistics are kept to a minimum. However, as a feature of the book is its emphasis on the need for quantitative results, a knowledge of elementary algebra and also an ability to interpret simple regression statistics would be helpful. For those readers who are deficient in these areas, Appendix 1 provides a brief overview of some of the techniques required.

Potentially the subject-matter of a book such as this is voluminous, embracing as it does elements of macroeconomic and monetary theory, the theory of macroeconomic policy, econometrics and an assessment of recent policy measures. No doubt there is a reasonable consensus amongst professional economists on what ought to appear in a textbook dealing with any one of these subject areas. However, in a 'hybrid' text such as this it is exceedingly difficult to decide on a reasonable balance both between and within these diverse subject areas and economists who specialise in one or other of these areas are bound to argue that some topic should have been treated in greater depth, or perhaps not included at all. Bearing in mind the aims of this text and its intended readership, it would therefore seem useful if I explain briefly the general principles that governed my choice of the appropriate balance between the economic theory of individual behaviour equations, an assessment of their empirical results, the behaviour of complete models and an analysis of recent policy measures.

Central to the book is an analysis of the main ideas of three schools of thought on economic policy. I have sought to present a coherent account of these views by providing the reader with relevant material that is not covered adequately in existing macroeconomics textbooks and may sometimes only be found by searching through economics journals. At all stages I have tried to emphasise the policy implications of the subject-matter under discussion. This is partly because I believe that an important reason for studying macroeconomics is to assess the usefulness of alternative policy prescriptions and partly because I think this approach stimulates and maintains the interest of the reader. However, in pursuing this objective I have not considered it necessary to present a detailed account of recent economic policy measures; instead I have chosen to emphasise policy aspects by spending more time than do existing texts in analysing the quantitative results that one obtains using complete models of the economy. In general this 
book perhaps places more emphasis on the implications of empirical results, on individual behavioural equations, rather than on their theoretical underpinnings. Nevertheless, where the subjectmatter is relatively new, or usually omitted from other texts, or where in my experience students find difficulty in understanding a topic, I have spent more time discussing theoretical aspects. The New Cambridge expenditure equation, rational expectations and international monetarist models probably fall under the first heading, and export prices and real wages under the second heading. Under the final heading I include the determination of the money supply. Here I have tried to introduce an element of portfolio choice into the simple bank multiplier and also tried to highlight the linkage between fiscal and monetary policy through the government budget constraint, though this has not been done in a full general-equilibrium approach as in the Blinder and Solow (1973) type of analysis. I have also tried to present a clear, albeit simple, account of the theory behind the price-expectationsaugmented Phillips curve and the natural rate of unemployment. Similar considerations to the above were applied when deciding on the inclusion of detailed empirical evidence on individual behavioural equations. Representative rather than exhaustive references, as well as a list of selected reading at the end of the book, enable the interested reader to follow up these matters further.

Some readers might consider the omission of the set of topics which loosely come under the heading of 'the theory of macroeconomic policy' somewhat strange. While it is undoubtedly true that optimal stabilisation policy provides a useful approach to the conduct of macroeconomic policy under uncertainty, it is not dealt with here because it is mathematically too complex and its practical application to macroeconomic policy and forecasting is, as yet, in its infancy. The 'second-best' solution adopted here is to take account of such uncertainties in a more eclectic (albeit less rigorous) fashion. The deficiencies of the Mundell and Swann diagrams are well documented and their practical relevance is limited, and therefore these theoretical constructs are not discussed. Although it is widely used, the $I S-L M$ diagrammatic approach to macroeconomic analysis also has well-known theoretical limitations and I have found that the average student seems to learn more about draughtsmanship than economics when using this approach. On 
this question I have compromised by alluding to the $I S-L M$ diagrammatic approach but presenting the relevant analysis in algebraic form.

In extracting the central elements of the three main schools of thought on macroeconomic policy I hope that the selection process has not been unduly influenced by my own views and (necessarily) limited knowledge and experience. After completing the book I hope the reader agrees that the emphasis has been on those areas of analysis that have practical relevance, that he is more aware of the importance of other related areas of economics and that he is encouraged to study these problems further.

The structure of the book is outlined at the end of Chapter 1 . 


\section{Acknowledgements}

I have received a great deal of help and encouragement from friends and colleagues in producing this text. Martin Fetherston, Wynne Godley and other members of the Cambridge Economic Policy Group kindly provided valuable comments on the chapter dealing with New Cambridge views. Many colleagues at the National Institute provided helpful suggestions on all aspects of the text; in particular, Tom Sheriff, David Savage, David Worswick, Paul Ormerod and Brian Henry deserve special mention. My thanks to Joe Grice and Honor Stamler for providing me with their results on New Cambridge expenditure equations, and to Andrew Britton for his comments on an earlier draft of the book. John Evans, James Foreman-Peck and John Foster patiently read through the typescript and made many constructive criticisms. Of course, any errors and omissions that remain are my own.

The main weight of typing and retyping fell upon Jan Borders and Rita Leach, assisted by Pat Addison, Norma Phayer and Fran Robinson. My thanks to them all. Finally, I must apologise to my family for somewhat underestimating the time required to write this book. I hope my numerous absences and monomania of the last year are rectified in the future.

K. C.

The author and publishers wish to thank the following, who have kindly given permission for the use of copyright material:

The Cambridge Economic Policy Group for a table from an article by Tarling and Wilkinson in Economic Policy Review, no. 2 (1976).

The Economic Intelligence Department, Bank of England, for a table from the Quarterly Bulletin (March 1978). 